rzystaniem z podręczników obcojęzycznych. Wiem, że zamiarem Profesora jest stworzenie w Krakowie w ciągu najbliższych lat specjalności ormiańskiej na Uniwersytecie Jagiellońskim. Aby ten cel osiągnąć, recenzent pragnie podzielić się kolejnymi przemyśleniami na kanwie lektury omawianej gramatyki i przedstawić pewne postulaty pod adresem Mistrza, a mianowicie, że są potrzebne kolejne pomoce do nauki ormiańskiego, bo bez nich trudno będzie polskim studentom w możliwie szybkim czasie przyswoić sobie odpowiednią wiedzę. Jak już wspomniano, omawiana Gramatyka jest gramatyką opisową do trzech języków ormiańskich, a do nauki potrzebny jest praktyczny podręcznik z tekstami, komentarzem i słowniczkiem. Do dziś w Niemczech używa się jako pierwszego podręcznika A. Meillet (Altarmenisches Elementarbuch, Heidelberg 1913), który oprócz wykładu posiada kilka tekstów i słowniczek wraz $\mathrm{z}$ odniesieniem do danego paragrafu w podręczniku, przez co ułatwia rozwiązanie problemu gramatycznego. W związku z tym rodzą się następujące sugestie, aby do każdego $z$ tych trzech języków powstały osobno praktyczne podręczniki, tak jak istnieją w języku francuskim czy niemieckim oraz słownik ormiańsko-polski.

Omawiane wiekopomne dzieło prof. A. Pisowicza stało się podstawą do otrzymania profesury i przyczyni się z pewnością do szybkiego wzrostu zainteresowania kulturą ormiańską w Polsce.

Ks. Jerzy Woźniak CM - Kraków, UJ

\title{
Ks. Andrzej UCIECHA, Ascetyczna nauka w, Mowach” Afrahata, Katowice 2002, Studia i Materiały Wydziału Teologicznego UŚ w Katowicach nr 3, Księgarnia św. Jacka, ss. 192.
}

Recenzowana książka ks. Andrzeja Uciechy, kapłana diecezji katowickiej i pracownika dydaktycznego Wydziału Teologicznego Uniwersytetu Śląskiego, jako rozprawa doktorska, jest pierwszą monografią z zakresu syrologii napisaną przez Polaka i wydaną w Polsce z zastosowaniem na kilkudziesięciu stronach oryginalnego tekstu syryjskiego perskiego mędrca Afrahata i podaniem jego thumaczenia. Autor doszedł do takiego sukcesu po czterech latach studiów języka syryjskiego w Katolickim Instytucie w Paryżu i po odbyciu studiów patrystycznych w ATK w Warszawie. Cytowanie tekstu syryjskiego w obecnych polskich warunkach stało się możliwe dzięki technice komputerowej, która znosi, a może tylko zmniejsza, bariery i różnice między polską a światową nauką.

Książka autora składa się ze wstępu i czterech rozdziałów. We wstępie Autor wskazuje na syrologów XX wieku, którzy zajmowali się twórczością Afrahata (J. Parisot, P. Schwen, L. Haefeli, J. Hausherr, S. Funk, J. Neusner, 
F. Gavin, I. Ortiz de Urbina, A. Spijkerman, J.G. Snaith, M.J. Pierre, P. Bruns, a w Polsce: A. Fic, W. Kania, J. Woźniak). W rozdziale pierwszym: „Historyczny kontekst ascetycznej nauki Afrahata" (s. 21-61) Autor omawia historyczno-kościelne środowisko ascezy na przykładzie „synów przymierza” środowiska żydowskiego i pozażydowskiego oraz stosunek Afrahata wobec ascezy w herezjach i w enkratyzmie. W rozdziale drugim: „Antropologiczne elementy ascetycznej nauki Afrahata" (s. 62-97) ks. Uciecha omawia funkcje czterech elementów istoty ludzkiej (ciało, dusza, serce, duch) w relacji do ascezy chrześcijańskiej oraz relacje do kobiety. W rozdziale trzecim: „Teologiczne motywy ascetycznej nauki Afrahata" (s. 98-131) Autor ukazuje najpierw najważniejszy motyw ascezy, a więc wątek chrystologiczny na przykładzie Chrystusa jako ascety. Asceza Chrystusa realizowała się na czterech płaszczyznach: Chrystus jako zwycięzca szatana, Chrystus jako zwycięzca cierpienia i śmierci, Chrystus jako wzór pokory, Chrystus jako samotnik. Następnie autor omawia pneumatologiczne i eschatologiczne (sąd, odpłata, niebo) wątki w ascezie. W rozdziale czwartym: „Ideały ascetyczne synów przymierza" (s. 132-174) Autor charakteryzuje grupę syryjskich ascetów „synów przymierza” poprzez ukazanie roli wątku ,,atlety”, roli aksenii czyli zachowania dystansu do świata oraz znaczenie ideału ,życia anielskiego" wyrażającego się w nieustannym czuwaniu i ideale czystości. W końcowej części książki znajduje się „Zakończenie” (s. 175-180), „Bibliografia” (s. 181-185) i „Streszczenie” w języku angielskim (s. 186-192).

Zapytajmy się teraz, jakie są osiągnięcia Autora dzięki tej monografii? 1). Niewątpliwym osiągnięciem w skali ogólnopolskiej jest podjęcie tematu pracy doktorskiej z zakresu patrologii syryjskiej, co na polskich uniwersytetach nie zdarzyło się jeszcze po okresie II wojny światowej. Opracowanie tematu wymaga najpierw znajomości języka, choćby w zakresie podstawowym. Do dziś język syryjski nie jest nauczany w Polsce w wystarczającym wymiarze, aby można było pisać monografię. Chodzi tutaj o cztery semestry nauki języka plus dwa semestry ćwiczeń językowych w ramach proseminarium. Ks. Uciecha miał to szczęście studiować język syryjski w znanej od stu lat szkole języków orientalnych Instytutu Katolickiego w Paryżu. W związku z pisaniem monografii zachodzi potrzeba kwerendy w bibliotekach zagranicznych, gdyż w Polsce brakuje wielu książek z języków orientalnych. 2). Ks. Uciecha zrealizował plan pracy w sposób nowatorski, jak na polskie warunki, a mianowicie poprzez cytowanie oryginalnego tekstu syryjskiego na wielu stronach z podaniem polskiego thumaczenia. Czytając omawianą książkę czytelnik odnosi wrażenie, jakby obcował z samym autorem Afrahatem z IV wieku. W warunkach polskich jest to wielka nowość, gdyż od wielu lat negowano w kręgach teologów przytaczanie długich wątków w języku oryginalnym, a zwłaszcza w języku orientalnym. To co uczynił ks. Uciecha, można nazwać przełamaniem barier i wprowadzaniem polskiej nauki na tory międzynarodowe. Do- 
tychczas, jeżeli chodzi o patrologię orientalną, pojawiały się prace z cytowaniem tekstu oryginalnego jedynie z patrologii koptyjskiej. Teraz zaś po tym precedensie należy oczekiwać podobnych monografii, dotyczących pisarzy armeńskich, gruzińskich, etiopskich, arabskich, pisanych przez polskich studentów teologii. 3). Kolejnym osiągnięciem ks. Uciechy jest rozdział czwarty, w którym charakteryzuje wyczerpująco (w oparciu o analizy poprzednich rozdziałów) duchowość „,synów przymierza”, i w ten sposób przybliża polskiej kulturze tę problematykę.

A teraz zapytajmy: jakie są niedociągnięcia i braki w tej monografii? 1). Pierwszym poważnym niedociągnięciem Autora jest sprawa transkrypcji tekstu syryjskiego alfabetem łacińskim. Jest to zagadnienie bardzo trudne i skomplikowane i przeważnie autorzy zagraniczni podają we wstępie zasady transkrypcji, gdyż nie ma w tej sprawie jednej szkoły; zwykle nie stosuje się całkowitej transkrypcji uwzględniając begadkepat, jak w języku hebrajskim, gdyż syryjski jest językiem semickim, podobnie jak hebrajski. Nawet autorzy współczesnych gramatyk do języka syryjskiego nie stosują całkowitej transkrypcji (Thackston, Muraoka). Oprócz transkrypcji istnieje również transliteracja. Nawet specjaliście syrologowi, transkrypcja nasuwa poważne trudności, gdyż dany tekst nie zawsze zaznacza podwojenia spółgłoski (dagesz forte), a to trzeba się domyślać. Recenzent nie zwróciłby nawet uwagi na transkrypcję syryjskiego tekstu, gdyby nie rażące błędy, które wskazują na poważny brak głębszej znajomości syryjskiego, a co za tym idzie - książka owa znajdzie się zapewne również w bibliotekach zagranicznych i wówczas tamtejsi syrologowie i semitolodzy urobią sobie negatywne zdanie o polskiej syrologii. Ks. Uciecha nie stosuje do transkrypcji zjawiska begadkepat, chociaż niektórzy to robią odnośnie spółgłosek k i p, co powinno być powiedziane. Ponadto, podobnie jak w hebrajskim, spotykamy matres lectionis - spółgłoski, które wzdłużają samogłoski, a ich się nie transkrybuje. Tutaj w każdym przypadku ks. Uciecha transliteruje takie spółgłoski, jak w następujących przykładach (chodzi tutaj między innymi o znane partykuły często występujące oraz rzeczowniki): geyr (s. 36. 47) a powinno być gēr; deyn (s. 37) a powinno być dēn; beyt (s. 49) a powinno być bēt (y jest mater lectionis), por. L. Palacios, Grammatica syriaca, Roma 1954, s. 11 - dēn. Poza tym transkrypcja jest zbędna i można było ją opuścić, a dzieło miałoby trwałą wartość również dla uczących się syryjskiego.

2). Drugim niedociągnięciem są braki bibliograficzne: a). W źródłach podano jedynie wydanie tekstu Afrahata przez J. Parisota (s. 181), a opuszczono pierwsze jego wydanie - W. Wright, The Homilies of Aphraates, the Persian Sage, edited from Syriac Manuscripts of the fifth and sixth Century in the British Museum, London 1869. b). W tłumaczeniach nie wymieniono żadnego polskiego przekładu pisma Afrahata, mimo iż ks. A. Fic przełożył jego mowę XVIII o dziewictwie (1930), a ks. W. Kania mowę IV o modlitwie (1989) i mowę 
X o pasterzach (1996). Ponadto podano tu dzieło, które jest jedynie monografią (s. 181) - J. Neusner, Aphrahat and Judaism. The Christian-Jewish Argument in Fourth-Century Iran, Leiden 1971. c). W paragrafie czwartym bibliografii: „Encyklopedie i Słowniki” ks. Uciecha cytuje tylko dwóch autorów: L. Costaz, Dictionnaire syriaque-français, Beyrouth 1986; C. Brockelmann, Lexicon syriacum, 1928. Już w tych opisach są nieścisłości, gdyż Costaz i Brockelmann nie są redaktorami, lecz autorami, co zmienia postać rzeczy, a miejsce wydania słownika Brockelmanna nie jest tajemnicą, jest nim Halle, znany ośrodek orientalistyczny XVIII i XIX wieku. Ponadto, podanie hasła bez zaznaczenia encyklopedii budzi podejrzenie, gdyż do dzisiaj nie ukazała się żadna encyklopedia syrologiczna, a jedynie jest przewidziana, co może nastąpić za dwa lata pod redakcją G. Kiraza. Należało się spodziewać bogatszej bibliografii, w której brakuje m.in. 2 artykułów o Eucharystii (1988) i mariologii (1990) u Afrahata, opublikowanych w „Vox Patrum” oraz jego refleksji o modlitwie (1981) w „Tarnowskich Studiach Teologicznych”. Brak również pełniejszej i reprezentatywnej bibliografii dla syrologii na przykładzie: a). Gramatyki - L. Palacios, Grammatica syriaca, Roma 1954; C. Brockelmann, Syrische Grammatik, Leipzig 1981 (13 wyd.); Th. Nöldeke, Kurzgefasste syrische Grammatik, Leipzig 1898. Do dziś posiadamy jedynie dwie naukowe gramatyki: niezastąpioną gramatykę Th. Nöldeke oraz C. Brockelmanna, która zawiera dużo tekstów ze słowniczkiem oraz bogatą bibliografię, a naukę najlepiej zacząć od L. Palaciosa. b). Słowniki - istnieją jedynie dwa słowniki. Jeden już wymieniony C. Brockelmanna oraz najbardziej kompletny pisany przez 40 lat pod red. R. Payne Smith, Thesaurus Syriacus, t. 1-2, Oxford 1868-1901, oraz bardzo praktyczny skrót tego słownika: J. Payne Smith (Mrs Margoliuth), A Compendious Syriac Dictionary, Oxford 1903. Zauważamy tutaj błąd metodologiczny. Powinno się objaśniać występujące terminy syryjskie w oparciu o słownik Thesaurus Syriacus jako najbardziej wiarygodny i obszerny i wówczas praca byłaby bardziej ubogacona.

Nasuwa się pytanie: jak należy studiować syrologię? Najlepiej zacząć wcześniej od łaciny, greki, hebrajskiego, aramejskiego i arabskiego, gdyż język syryjski jako język semicki jest również językiem literatury chrześcijańskiej. Powoli nadchodzą czasy również na syrologię w Polsce. Krzystof Sachryn, student IR UJ pisze rozprawę doktorską na temat poglądów filozoficznych Ignacego z Niniwy, a w semestrze zimowym 2002/2003 zgłosiło się na język aramejski do recenzenta w IR UJ trzech studentów z I roku, dobrze przygotowanych w Liceum Nowodworskiego w Krakowie, którzy już mieli łacinę, grekę i hebrajski. W przyszłości będzie im łatwiej studiować syryjski. Przed stadium finalnym rozpraw z zakresu języków semickich i syrologii możemy się konsultować w Krakowie z prof. dr hab. Andrzejem Zaborskim, znawcą 40 języków, który od niedawna kieruje Zakładem Języków Afroazjatyckich w UJ, i jest gotowy pomagać innym ośrodkom i doradzać, w jaki sposób podnosić po- 
ziom. Ponadto recenzent od 20 lat prowadzi prywatny Instytut Syrologiczny i dlatego jest zainteresowany właściwym rozwojem polskiej syrologii. Ks. Andrzejowi Uciesze zaś należy życzyć dalszego doskonalenia warsztatu badawczego i następnych publikacji.

Ks. Jerzy Woźniak CM - Kraków, UJ

\section{Michael ABDALLA, Kultura żywienia dawnych $i$ wspótczesnych Asyryjczy- ków. Uwarunkowania spoteczno-kulturowe, Warszawa 2001, Wydawnictwo Dialog, ss. 430.}

Książka dra Michaela Abdalli, poznańskiego orientalisty i specjalisty od technologii żywności w poznańskiej Wyższej Szkole Rolniczej, jest pierwszą tego typu publikacją nawet w skali światowej, (jak zauważa wydawca na ostatniej stronie okładki), która omawia produkty żywienia mieszkańców nad Eufratem od najdawniejszych czasów aż po współczesność. Chodzi tutaj o ludność asyryjską nie w znaczeniu odnoszącym się do czasów wielkiego imperium asyryjskiego (III-I tysiąclecie), ale o chrześcijan należących do Asyryjskiego Kościoła (Assyrian Church). W książce tej Autor uporczywie lansuje tylko jedną nazwę - Asyria lub asyryjski, co należy rozumieć jako Syria chrześcijańska i syryjski, gdyż ci którzy uważają się za członków współczesnej wspólnoty asyryjskiej są częścią Kościoła Syryjskiego i tak się uważa w innych krajach i w literaturze fachowej, a zwykły polski czytelnik nie może czuć się okłamany.

Dr Michael Abdalla znany jest w Polsce $\mathrm{z}$ artykułów zamieszczanych przeważnie w czasopismach „Lud” i „Przegląd Orientalistyczny”, obecnie zaś napisał obszerną monografię jako podstawę do habilitacji na Wydziale Historycznym Uniwersytetu Poznańskiego. Urodził się w 1952 roku, na wsi północnowschodniej Syrii . Od r. 1971 studiował w Akademii Rolniczej w Poznaniu, gdzie uzyskał w 1977 r. stopień magistra, a w 1980 stopień doktora technologii żywności. Sam z domu wyniósł znajomość języka arabskiego i neosyryjskiego i dlatego pełni funkcję lektora języka arabskiego od wielu lat w Katedrze Orientalistyki w UAM w Poznaniu a od kilku lat naucza także języka syryjskiego .

Prezentowana książka dzieli się na 7 rozdziałów. Najpierw wprowadzenie "Od autora" (s. 9-12) pełni funkcję rozdziału I. Następnie w rozdziale II (s. 1326): „Wstęp”, Autor omawia kulturowe dziedzictwo chrześcijan asyryjskich w odniesieniu do żywności i żywienia oraz uzasadnia potrzebę studiów w tej dziedzinie. W rozdziale III (s. 27-161): „Zboża i produkty zbożowe w tradycji Asyryjczyków" znajduje się pierwszy paragraf dotyczący epoki patrystycznej pt. „Pszenica i chleb w pracach chrześcijańskich pisarzy asyryjskich” (s. 27-34). 